\title{
Globalization and vulnerable populations in times of a pandemic: A Mayan perspective
}

\author{
Claudia Ruiz Sotomayor ${ }^{1 *}$ (D) and Alejandra Barrero ${ }^{2}$
}

\section{Abstract}

Global health conditions are marked by inequities due mostly to poverty and lack of acce to lo are services. In a Pandemic setting, Mayan Communities in the Quintana Roo State in Mexico are a soo xample of how these disparities are exacerbated. First, they may have difficulty in adhering to directives tay hon firom work because of the nature of their job, and the necessity to work, their living conditions are marke $\mathrm{v}$ crowding and sometimes lack of basic sanitation. Other susceptibilities generally considered are the un ing hos lactors and medical conditions that may increase the risk of disease or of complications of dise e. Ir aeneral, our native communities experience a high degree of socio-economic marginalization and are at disp. prtionate risk in public health emergencies, becoming even more vulnerable during this global par-smic, on $y$ to factors such as their lack of access to effective monitoring and early-warning systems, and adequate

\section{Introduction}

Globalization brings to the table free flow of trade, investments, and profits across nations with the hore of improving global integration that eventually will p. the best economic, social, and political outcomes for manity. From a public health perspective, s alizatio, has improved health and life expectancy in ma nopulations, but unfortunately, it has endangered/many others due to the erosion of the env onment, the global division of labor, the exacerbation o e ri h-poor gap between and within countric and the accelerating spread of consumerism [1].

As a result, global hear conditions are marked by inequities due mostly $p$ ack and ack to healthcare services. In a 'andemic setting, these disparities are exace 1 d. Liter, cure from the influenza pandemic show that $t$. are several causes for such event $[2,3]$. Fi st, low-inco, ne and minority workers may have difficuit, $n$ adh ring to directives to stay home from wo beca of the nature of their job, and the

* Tspomance: CRS145@georgetown.edu

'Pelle Center for Clinical Bioethics, Georgetown University, Washington DC, US,

Full list of author information is available at the end of the article new ity to work [4], their living conditions are marked by cr wding and sometimes lack of basic sanitation [5]. susceptibilities generally considered are the underlying host factors and medical conditions that may increase the risk of disease or of complications of disease. Our native communities experience a high degree of socio-economic marginalization and are at disproportionate risk in public health emergencies, becoming even more vulnerable during this global pandemic, owing to factors such as their lack of access to effective monitoring and early-warning systems, and adequate health and social services [2].

\section{The Mayan experience}

A good example of how globalization affects vulnerable populations is the Mayan Communities in the Yucatan Peninsula. In my early years of practicing physician, I volunteered at a non-profit organization that provided community health care to Mayan Communities in the State of Quintana Roo, Mexico. The experience not only shaped my future career choices, but taught me the complexity that entails providing adequate healthcare to vulnerable populations. I witness a rooted distrust of the healthcare system, the corruption of the government, a

\section{$\triangle B M C$}

(c) The Author(s). 2020 Open Access This article is licensed under a Creative Commons Attribution 4.0 International License, which permits use, sharing, adaptation, distribution and reproduction in any medium or format, as long as you give appropriate credit to the original author(s) and the source, provide a link to the Creative Commons licence, and indicate if changes were made. The images or other third party material in this article are included in the article's Creative Commons licence, unless indicated otherwise in a credit line to the material. If material is not included in the article's Creative Commons licence and your intended use is not permitted by statutory regulation or exceeds the permitted use, you will need to obtain permission directly from the copyright holder. To view a copy of this licence, visit http://creativecommons.org/licenses/by/4.0/ The Creative Commons Public Domain Dedication waiver (http://creativecommons.org/publicdomain/zero/1.0/) applies to the data made available in this article, unless otherwise stated in a credit line to the data. 
high degree of socio-economic marginalization, and many underlying host factors and medical conditions that increase the risk of diseases or of disease complications. These communities are often immersed in the jungle with low infrastructure, poor sanitation, and no access to health and social services. Due to the financial constraints, many people from the communities go to larger cities -such as Cancun- to work in the hotel industry.

Before the coronavirus-era tourism was thriving, cruise ships were coming and going to and from the Riviera Maya, spring breakers were enjoying the beaches, people all around the world traveled to witness the natural beauty of this land. Unfortunately, along with their contribution to the economy, this year tourists also brought SARS-COV-2 with them. The first three confirmed cases in the area were announced on March 10th, and it was on March the 30th when social distancing measures were issued, hotels were closed and people had to go back to their hometowns. And so, they took the virus with them. To warn the population, Mexican government issued messages via radio and brochures in their native language, but the lack of health community centers on site and difficult transportation from their town to the city complicates the situation because it is difficult to ensure adequate education. Even though the $10 \mathrm{cal}$ government has established medical brigades on . ag lar basis with the current contingency it is uncrear. v many of these brigades are working due to 4 fact tha medical personnel are recruited to assist in fron ines at local hospitals.

Another major problem- often fo rotten in a globalized world- is the cultural context. are a e still very traditional Mayan communit that sometimes clash with the western view of medicine $r$ healing. Understanding the interpretatin of ill ess, health and healthcare of the comm, ties is crucial when setting up preparedness plan is ightrul consideration of the community co\% thelps, evelop a language that is appropriate for then nd avoids clashing cultures. In the case of the Miayas, it)o important to note that life, illness and hea. in errelated events, and they have a direct rel-'n w thar gods and their ancestors. Life is interlate with the physical world and the gods from the s, earm, and underworld. This interconnectedness is refle $d$ in the Mayan view of illness [6]. When it comes to healthcare choices, Mayans have a communitarian approach where a decision is not taken autonomously by one individual, but rather as a communal decision where the extended family and the H-men (Mayan spiritual healer) participate [7]. Mental reasoning is not taken into consideration when making healthcare choices, because it is believed that the human heart is the receptor of the divine essence that comes from the Heart of the
Sky and the Heart of the Earth, therefore it is only the heart that enables people to use their good sense and not the brain [8].

\section{Final remarks}

With this background one can imagine that im social distancing practices due to a novel vir con be difficult if not addressed in a culturally sensitive nner It is well known that pandemic preparedness an sponse must occur within a social, cuitu and historical context of preexisting health isparitic 91. In this case, understanding their views on health, Allness and healthcare and including the $4-\mathrm{m}$ in the planning and implementation process of ventur and mitigation strategies is crucial to ain the st of the community. Building bridges of on unication and trust between the leaders of our native a munities is key to be able to protect the $\mathrm{Co}$ munities and to improve their adherence to soch 1 gunes. However, in a crisis there may not be enou time to build those bridges, it is likely that actions will reec to take place.

With thi ynfortunate event, one thing is clear, glo. zation has unintended health risks, and marginalred ommunities are left in an even more vulnerable $p$ ition.

\section{Acknowledgements}

To the people in Quintana Roo, Mexico with whom I worked, specially Father Izquierdo and Father Jiri, and to Dr. Alejandra Barrero who facilitated the communication between the author and some medical personnel in the area.

\section{Authors' contributions}

Claudia Sotomayor and Alejandra Barrero are the authors of this manuscript. The author(s) read and approved the final manuscript.

\section{Authors' information}

Adjunct Assistant Professor Internal Medicine Georgetown University Medical Center and Pellegrino Center for Clinical Bioethics.

Funding

Not applicable.

Availability of data and materials

Not applicable.

Ethics approval and consent to participate

Not applicable.

Consent for publication

I consent the publication of this commentary.

\section{Competing interests}

The authors declare that they have no competing interests.

\section{Author details}

${ }^{1}$ Pellegrino Center for Clinical Bioethics, Georgetown University, Washington DC, USA. ${ }^{2}$ Department of Neonatology, Beth Israel Deaconess Medical Center, Boston, Massachusetts Harvard Medical School, Department of Pediatrics, Boston, Massachusetts, USA. 
Received: 22 July 2020 Accepted: 27 August 2020

Published online: 12 October 2020

\section{References}

1. Botero. El cambio climático y sus efectos en la biodiversidad en América Latina: Comisión Económica para América Latina y el Caribe; 2015. p. S.1501295.

2. United Nations. COVID-19 and Indigenous peoples. 2020. Available at: https://www.un.org/development/desa/indigenouspeoples/covid-19.html.

3. Anon. Responding to Healthcare Disparities and Challenges With Access to Care During COVID-19. 2020;4(1):117-28 [online]. Available from: https:// www.liebertpub.com/doi/abs/10.1089/heq.2020.29000.rtl.

4. Quinn SC, Kumar S, Freimuth VS, Musa D, Casteneda-Angarita N, Kidwell K. (2011) racial disparities in exposure, susceptibility, and access to health care in the US H1N1 influenza pandemic. Am J Public Health. 2011:101(2):285-93 http://proxy.library.georgetown.edu/login?url=https://search.proquest.com/ docview/847329699?accountid=11091.

5. Blumenshine, Philip, et al. "Pandemic Influenza Planning in the United States from a Health Disparities perspective.(PERSPECTIVE)." Emerging Infectious Diseases, vol. 14, no. 5, U.S. National Center for Infectious Diseases, May 2008, pp. 709-15, doi:https://doi.org/10.3201/eid1405.071301.

6. Barrera-Bassols, Toledo. Ethno-ecology of the Yucatec Maya: symbolism, knowledge and management of natural resources. J Lat Am Geogr. 2005; 4(1):9-41. https://doi.org/10.1353/lag.2005.0021.

7. Faust. Cosmology and changing Technologies of the Campeche-Maya. Dissertation Graduate School of Syracuse University. Doctor in Philosophy in Anthropology. 1988.

8. Micalco. The use of numbers in embroidery in Tzeltal Mayan communities Cult Hist Psychol. 2013;3:98-105.

9. Plough, Alonzo, et al. "Pandemics and Health Equity: Lessons Learned from the H1N1 Response in Los Angeles County. (Report)." Journal of Public Health Management and Practice, vol. 17, no. 1, Lippincott Williams \& Wilkins, WK Health. 2011

\section{Publisher's Note}

Springer Nature remains neutral with regard to jurisdictional clai $\quad$ in published maps and institutional affiliations.

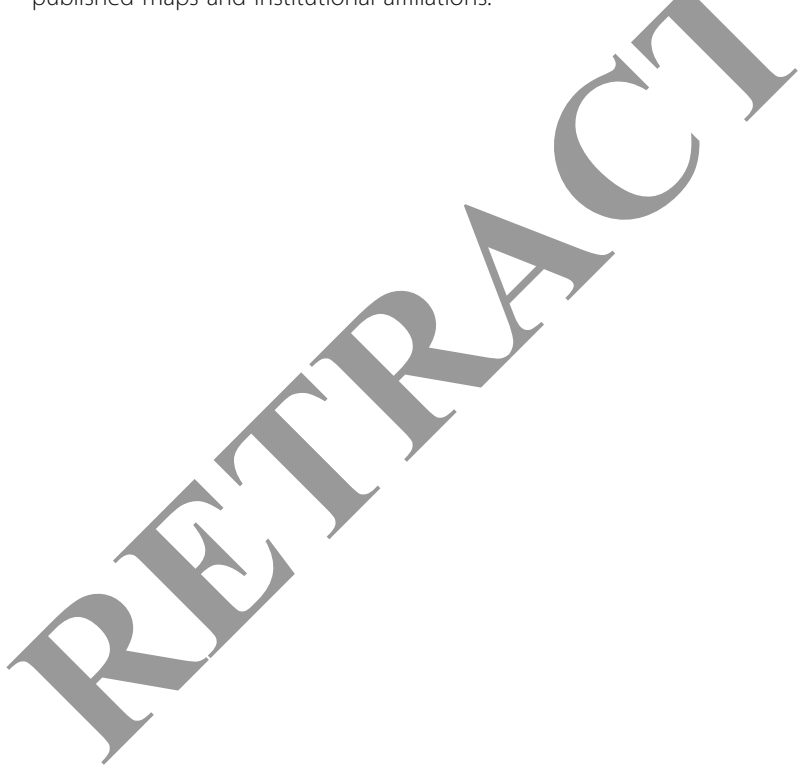

Ready to submit your research? Choose BMC and benefit from:

- fast, convenient online submission

- thorough peer review by experienced researchers in your field

- rapid publication on acceptance

- support for research data, including large and complex data types

- gold Open Access which fosters wider collaboration and increased citations

- maximum visibility for your research: over $100 \mathrm{M}$ website views per year

At BMC, research is always in progress.

Learn more biomedcentral.com/submissions 